\title{
EFFECT OF SUPPLEMENTARY FEEDING ON SHEEP SKIN AND COAT CHARACTERISTICS IN HALAIEB, SHALATEEN AND ABOU RAMAD TRIANGLE
}

\author{
Naglaa S. Badawy \\ Wool Production and Technology Department, Desert Research Center, El-Mataryia, Cairo, Egypt.
}

(Received $9 / 2 / 2016$, Accepted $10 / 5 / 2016)$

\section{SUMMARY}

$\mathrm{F}$

ifteen adult local ewes aged 2-4 years with an average body weight of $30 \mathrm{~kg}$ were employed to study the effects of grazing and supplementary feeding on wool follicles activity. Animals were randomly divided into three equal groups. The first group was kept in confinement (control, group 1) and fed on clover hay supplemented with concentrate feed mixture (1\% of BW), while the other two groups (2 and 3 ) were grazing the natural rangelands and supplemented with the same concentrate mixture ( 1 or $2 \%$ of BW, respectively). Animals raised in Hederbah valley, Shalateen Research Station from July 2013 to April 2014. At the end of the experiment, skin samples were taken and used to examine the follicle activity and their fibres in response to grazing and supplementary feeding. Results revealed that there is a significant increase in various primary follicle dimensions and their fibres of animals having the supplementary feeding with the double amount of concentrate except in the wall thickness which decreased significantly in all treated animals in comparison with the control group. The increase in the internal diameter of the follicles accompanied by a decrease in the follicles wall thickness was in relation to the increased values of the fiber diameter. Medulla thickness also showed an increased value by the double supplementary feeding. Grazing process showed a significant decrease in the external diameter and wall thickness of the primary follicles and in all secondary follicle dimensions in animals having $1 \%$ from body weight concentrate mixture in comparison with the control group. On the other hand, supplementary feeding level by $2 \%$ from body weight concentrate mixture showed a slight increase in all secondary follicle dimensions and their fiber diameters in comparison with the other grazed group. Histochemically, there is an excess protein and carbohydrate content in the outer root sheath of both primary and secondary wool follicles than that in the inner root sheath. Administration of double amount of concentrate resulted in a significant increase in the protein content in both sheaths of the primary follicles. An intermediate content was observed in the grazed group having concentrate $1 \%$ from body weight. The general carbohydrates showed a reversible trend and the intermediate value was detected in the control group. In secondary follicles, free grazing revealed a non significant decrease in the general protein contents in both follicle sheaths while the general carbohydrates showed an increase in grazed animal than the control group and in the supplemented group than the other two groups. Generally, the supplementary feeding increased the activity of the primary and secondary wool follicles and consequently the wool production and reduced the effect of grazing process.

Keywords: Skin, sheep, histology, histochemistry, supplementary feeding, grazing.

\section{INTRODUCTION}

Sheep are considered to be one of the most important grazing animals that can affect the social and economic status of people inhabiting arid and semi arid regions. It has an outstanding virtue; if required to, it can live and produce, at least wool, on the most sparse and inhospital grazing, and because of this ability it has always tended to be relegated to the less favorable environments for plant and animal growth. On the other hand, it is well known that they can be given the opportunity to produce at high levels with the highly productive pastures that are a feature of our modern farming.

Natural rangeland forages provide the least expensive source of nutrients for ruminants, while the efficiency of using these resources is being affected by many factors such as location, plant species, season of the year and supplementation (Askar et al., 2014).

Halaieb-Shalateen region has a vital strategic importance to Egypt as a border area between Egypt and Sudan. There are numerous constraints that affect sheep's performance, trading and marketing in this region. The most effective constraint is the erratic and short duration of rain precipitation which leads to long drought from April to October period (El-Shaer et al., 1997). This constraint causes shortage of feed 


\section{Badawy}

resources in that period which has a negative impact on sheep production thus the activities and social life of residents.

Grazing animals in arid and semi-arid regions are generally subjected to periods of under nutrition during extreme hot environment due to non availability of feed and poor pasture conditions, which in turn results in low productivity. The impact of nutrition on the wool growth of grazing animals has long been considered. The period of poor pasture growth or quality are reflected in a reduction in total fleece growth per animal and per unit area of grazed land.

Supplementation may be necessary to meet the nutrient requirements of grazing animals and improve their performance, (El-Shaer and Kandil, 1990). Also, Kochapakdee et al. (1994) reported that grazing alone may not be sufficient to optimizing live weight gain and wool production in sheep and goats.

This work aimed to study the effect of grazing and supplementary feeding on the histological and histochemical compositions of skin follicles and their fibres to fulfill proper approaches for improving skin follicle and wool production and consequently to achieve optimum social development in that region.

\section{MATERIALS AND METHODS}

The present study was carried out in Hederbah valley, Shalateen Research Station, Red Sea Governorate, Desert Research Center, Ministry of Agriculture and Land Reclamation, Egypt. The station lies $1400 \mathrm{~km}$ south east of Egypt and considered an arid region with natural rangelands for grazing animals. It lies between Latitude $\left(36^{\circ}, 52^{\prime}, 676^{\prime \prime}\right),\left(36^{\circ}, 45^{\prime}, 002^{\prime \prime}\right)$ and Longitude $\left(22^{\circ}, 59^{\prime}, 795^{\prime \prime}\right),\left(22^{\circ}\right.$, 59 , $992 “)$.

Fifteen adult local ewes aged 2-4 years with an average body weight of $30 \mathrm{~kg}$ were randomly divided into three equal groups. The experimental work was carried out during the period from (July, 2013 to April, 2014). The first group (control) were kept under open pens and fed on clover hay. The other two groups were usually move to pasture in 8 am and return in $4 \mathrm{pm}$ and grazed the natural rangeland plants mainly Panicum turgidum. At the morning, the concentrate feed mixture (CFM) was daily offered to animals at a level of $1 \%$ of body weight to the control group (group 1) and group 2, and at a level of $2 \%$ of body weight to group 3. Fresh water produced from condensation station at Ras-Hadarba valley was available ad libitum.

At the end of the experiment, skin samples were taken from the mid side region which is considered as a standard follicle population area over the whole skin surface (Schleger and Turner, 1960). Skin specimens were fixed in calcium formol for about 24 hours (Barker, 1958), washed and left for 24 hours in distilled water and preserved in $70 \%$ ethanol. The samples were dehydrated, cleared and impregnation was carried out in paraffin wax. From paraffin blocks transverse sections of 6-8 microns in thickness were prepared.

For general histological observations, sections were stained with heamatoxlyin and Eosin stain (Drury and Wallington, 1980). From the histological examination, the external and internal follicle diameters were measured and the wall thicknesses were calculated. Also, the wool fiber diameter and medulla thickness were measured.

For histochemical investigations, two different methods were used for the detection of some biochemical substances representing the wool follicle activity in the skin. Mercury bromophenol blue (Chapman, 1975) was used for the demonstration of general proteins and Periodic acid Schiff's reaction (Mc-Manus and Cason, 1950) for the detection of general carbohydrates.

Both histological and histochemical parameters were measured using Image analyzer software (Zen, 2012, Blue edition) and (device Carl-Zeiss micro-imaging G and bh) with lenses 10/0.847 and 40/0.65.

Data were statistically analyzed by SAS (2004) program using general linear models procedure (GLM) for analysis of variance and using the nutritional diets as sets, followed by Duncan Multiple Range Test to examine the significance between means. 


\section{RESULTS AND DISCUSSION}

Sheep skin has two kinds of follicles known as primary and secondary follicles. The primaries are usually the largest and arranged in groups of three with undefined number of secondaries. The primary trio with its associated secondary follicles constitutes the follicle group, which is the unit of wool production. The primary being usually the largest follicles tend to grow coarser fibres than the secondaries but the fundamental difference that distinguishes them in sheep skin was that the primaries have a sweat gland and erector muscle, whereas the secondaries have neither of these (Fig. 1). Both types do, however, have sebaceous glands. Follicle growth is ultimately under endocrine control and these hormones with influence follicular activity are in turn controlled by many environmental factors including photoperiod, temperature and nutrition.

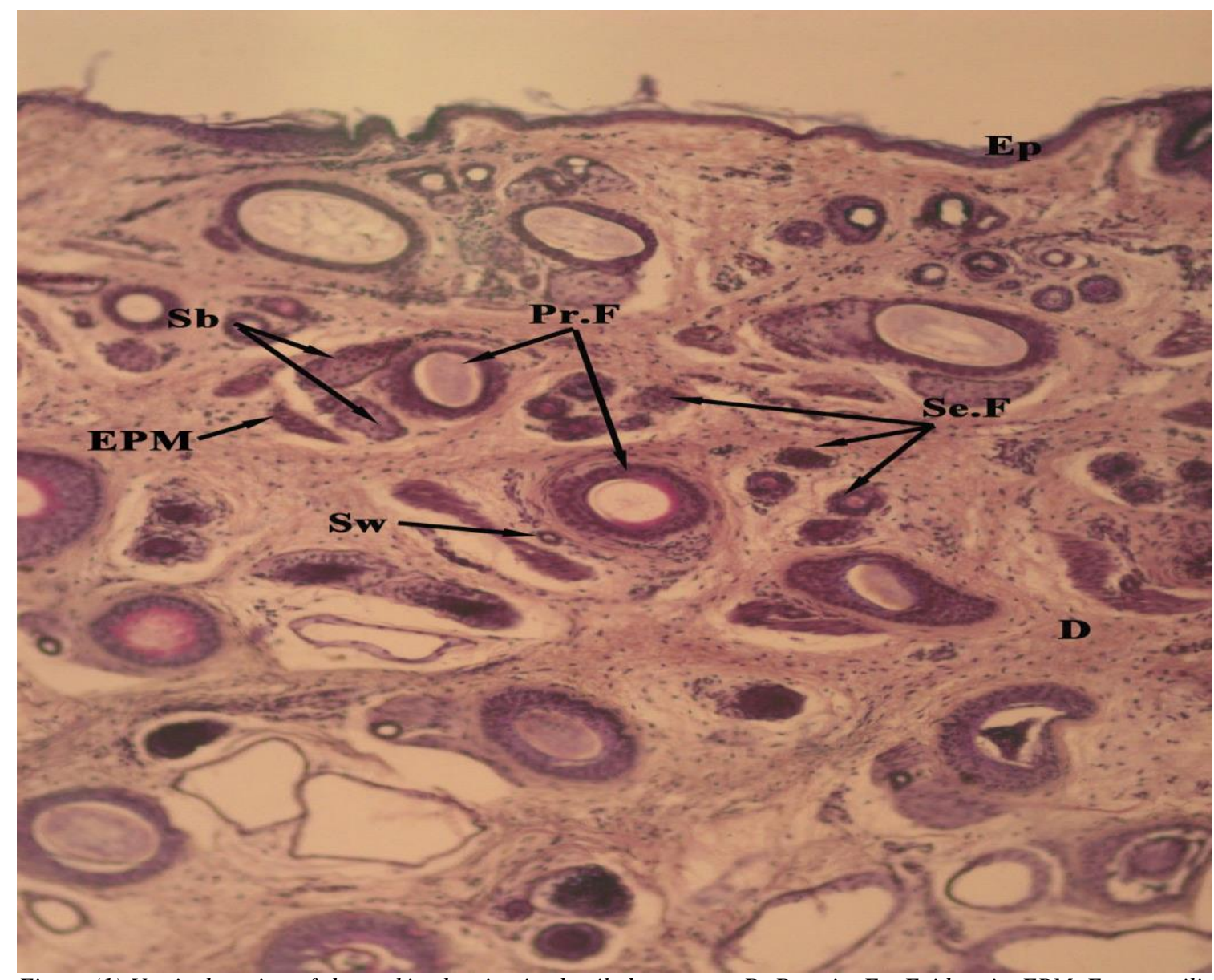

Figure (1):Vertical section of sheep skin showing its detailed structure. D, Dermis; Ep, Epidermis; EPM, Erector pili muscle; Pr. F, Primary follicles; Sc. F, Secondary follicles; Sb, Sebaceous gland; Sw, Sweat gland (Hx. E., X100).

Supplementary feeding affects significantly the primary wool follicle dimensions and its activity. Animals in group three which have the supplementary feeding with the double amount of concentrate have a significant increase $(\mathrm{P}<0.05)$ in all follicle dimensions except in the wall thickness (Table 1$)$.

The highest value of the external diameter was recorded in group (3) (203.82 \pm 3.35$)$ followed by the control group $(188.57 \pm 3.23)$ while the lowest value was found in animals of group (2) (174.500 \pm 3.83$)$. Also, internal diameter had the highest value in the same group $(163.46 \pm 2.85)$ which differed significantly $(\mathrm{P}<0.05)$ from group $(1)$ and $(2)(136.68 \pm 3.15,130.96 \pm 3.62)$, respectively.

The activity of the wool follicle culminates in the production of the fiber. Fiber diameter is the most important character affecting spinning count and the economic value of wool. The present study indicated that the effect of nutrition on the fiber diameter was highly significant (Table 1).

The highest average values of primary fiber diameter were recorded by animals in group (3) $(141.77 \pm 2.95)$. 


\section{Badawy}

Table (1): Mean values ( $\mu \mathrm{m} \pm \mathrm{SE}$ ) of primary wool follicle dimensions and their fiber diameters and medulla thickness in the skin of sheep at different nutritional supplementations.

\begin{tabular}{|c|c|c|c|}
\hline \multirow{2}{*}{ Item } & \multicolumn{3}{|c|}{ *Nutritional treatments } \\
\hline & Group 1 & Group 2 & Group 3 \\
\hline External diameter & $188.57 \pm 3.23^{b}$ & $174.500 \pm 3.83^{\mathrm{c}}$ & $203.82 \pm 3.35^{\mathrm{a}}$ \\
\hline Internal diameter & $136.68 \pm 3.15^{\mathrm{b}}$ & $130.96 \pm 3.62^{b}$ & $163.46 \pm 2.85^{\mathrm{a}}$ \\
\hline Wall thickness & $51.97 \pm 1.45^{\mathrm{a}}$ & $43.54 \pm 1.49^{\mathrm{b}}$ & $40.36 \pm 1.31^{\mathrm{b}}$ \\
\hline Fiber diameter & $118.63 \pm 3.26^{\mathrm{b}}$ & $111.06 \pm 3.72^{b}$ & $141.77 \pm 2.95^{\mathrm{a}}$ \\
\hline Medulla & $107.59 \pm 3.13^{\mathrm{b}}$ & $102.54 \pm 3.53^{\mathrm{b}}$ & $126.12 \pm 2.77^{\mathrm{a}}$ \\
\hline
\end{tabular}

The medulla is an important characteristic structure in sheep fleeces because of its association with hairiness and it followed the same trend with its fibre diameter, the greatest medulla thickness was exhibited by animals in group $(3)(126.12 \pm 2.77)$ followed by the control group $(107.59 \pm 3.13)$. This result is in harmony with that obtained by fibre diameter in the different groups. The significant increase occurred in all primary follicle dimensions of group (3) may be due to nutrition which alters the size of the follicle bulb, the size and number of cells in the germinative region of the bulb, the rate of bulb cell divisions and the ultimate size of the cortical cells, which make up the fibre. Abdou et al. (2006) concluded that the different levels of nutritional supplementation affected ultimately all primary follicle dimensions in Camels. Also, Kabir et al. (2004) recorded that productivity of goat may be increased by improving nutrition by either concentrates feeding or supply additional forages. So, grazing alone may not be sufficient for optimizing live weight gain and wool production as shown by Kochapakdee et al., (1994). On the other hand, Askar et al. (2012) and Ferrell et al. (1999) mentioned that the supplementary feeding is essential to increase feed intake and digestibility by improving dry matter and organic matter digestibility with sheep grazing poor quality forage.

The effect of grazing was observed between the animals which received the same amount of concentrate in groups $(1,2)$. A significant decrease in the external diameter $(174.500 \pm 3.83)$ and wall thickness $(43.54 \pm 1.49)$ of the primary follicles was found in animals of group (2) in comparison with those of the control group as shown in (Table 1).

At high levels of feeding, all follicles are in production and length growth rate is rapid and thickness of fibre is high. Fibre diameter influenced by the supply of nutrients available to wool follicles during the process of fibre growth as mentioned by (Whiteley, 1984) in Merino sheep and (Mc-Gregor, 1990) in Angora goats. Also, Rowe et al. (1989) stated that, as the level of supplement intake increased fibre diameter increased.

Khan et al. (2012) illustrated that in fleece, different diameters are determined initially by the genotype of the animal which sets the size and synthetic capacity of follicles, but are also considerably modified by external factors, especially nutrition and increased wool production obtained by improved nutrition is almost invariably associated with an increase in the mean diameter of the fibre. Mc-Gregor, (1990) reported that, although medullation is influenced markedly by genetic and age, possible affects of nutrition will be considered. Scobie et al. (1998) found that the high protein diets increased the proportion of medullation to 5.6 vs. 3.8 for low protein diets.

In case of secondary follicles, there was a significantly negative effect of grazing on their dimensions while fibre diameters improved slightly by the supplementary feeding. Table (2) possessed a significant increase in all secondary follicle dimensions of animals in control group than those in the animals of the other two groups.

Group (2) which have grazed animals fed $1 \%$ concentrates recorded the lowest mean values of all secondary follicle dimensions, the external and internal diameters were $(58.96 \pm 1.06$ and $27.48 \pm 0.55)$ versus $(73.66 \pm 0.96$ and $32.31 \pm 0.50)$ in control group, respectively. Fibres produced from secondary follicles showed the same trend in their diameters. The decreased follicle dimensions and its fibre diameters in secondary follicles of both grazed groups (2 and 3) may be due to rising temperature from free grazing in this arid region. 
Table (2): Mean values ( $\mu \mathrm{m} \pm \mathrm{SE}$ ) of secondary wool follicle dimensions and their fibre diameters in the skin of sheep at different nutritional supplementations.

\begin{tabular}{lccc}
\hline \multirow{2}{*}{ Item } & \multicolumn{3}{c}{ *Nutritional treatments } \\
\cline { 2 - 4 } & Group 1 & Group 2 & Group 3 \\
\hline External diameter & $73.66 \pm 0.96^{\mathrm{a}}$ & $58.96 \pm 1.06^{\mathrm{b}}$ & $62.33 \pm 1.46^{\mathrm{b}}$ \\
Internal diameter & $32.31 \pm 0.50^{\mathrm{a}}$ & $27.48 \pm 0.55^{\mathrm{b}}$ & $29.14 \pm 0.76^{\mathrm{b}}$ \\
Wall thickness & $41.34 \pm 0.74^{\mathrm{a}}$ & $31.48 \pm 0.81^{\mathrm{b}}$ & $33.19 \pm 1.12^{\mathrm{b}}$ \\
Fibre diameter & $21.77 \pm 0.42^{\mathrm{a}}$ & $18.80 \pm 0.46^{\mathrm{b}}$ & $19.96 \pm 0.64^{\mathrm{b}}$ \\
\hline
\end{tabular}

${ }_{*}^{*}$ Group $1=$ In-door treatment feeding clover hay and supplemented with concentrate feed mixture (1\% of BW), group 2 and $3=$ grazing treatments supplemented with concentrate feed mixture (1 and $2 \%$ of $B W$, respectively). In each row, figures followed by different letters are significantly different $(P<0.05)$.

This was in agreement with El-Ganaieny and Abdou (1999) who showed that there was a significant change occurred in the external and internal diameters of both follicle types during different seasons and this may be due to different rates of cell division associated with seasonal variations in climate. Studies by Badawy (2006) indicated that rising temperature in hot season decreasing all secondary follicle dimensions and its fibre diameters in sheep. On the other hand, experiments on Merino ewes exposed to high ambient temperatures during the later part of gestation (Cartwright and Thwaites, 2000) have shown that such conditions can appreciably reduce the number of secondary follicles in lambs at birth. The effects on the foetus appear similar to those of restricted maternal nutrient supply and may be a result of placental blood flow or in nutrient uptake by the foetus. The potential for Cashmere in particular may be influenced by nutrition in early life, as these fibres are produced by secondary follicles.

Wool is almost entirely composed of protein, the protein status of the animals is a good indicator of their nutritional and hormonal state to different forms of stress facing the animal and the determination of energy is very important in nutritional status assessment since it is reflected in animal productivity and health condition. Generally, there is an excess protein content in the outer root sheath of both primary and secondary wool follicles than that in the inner root sheaths in all groups studied (Fig.2).

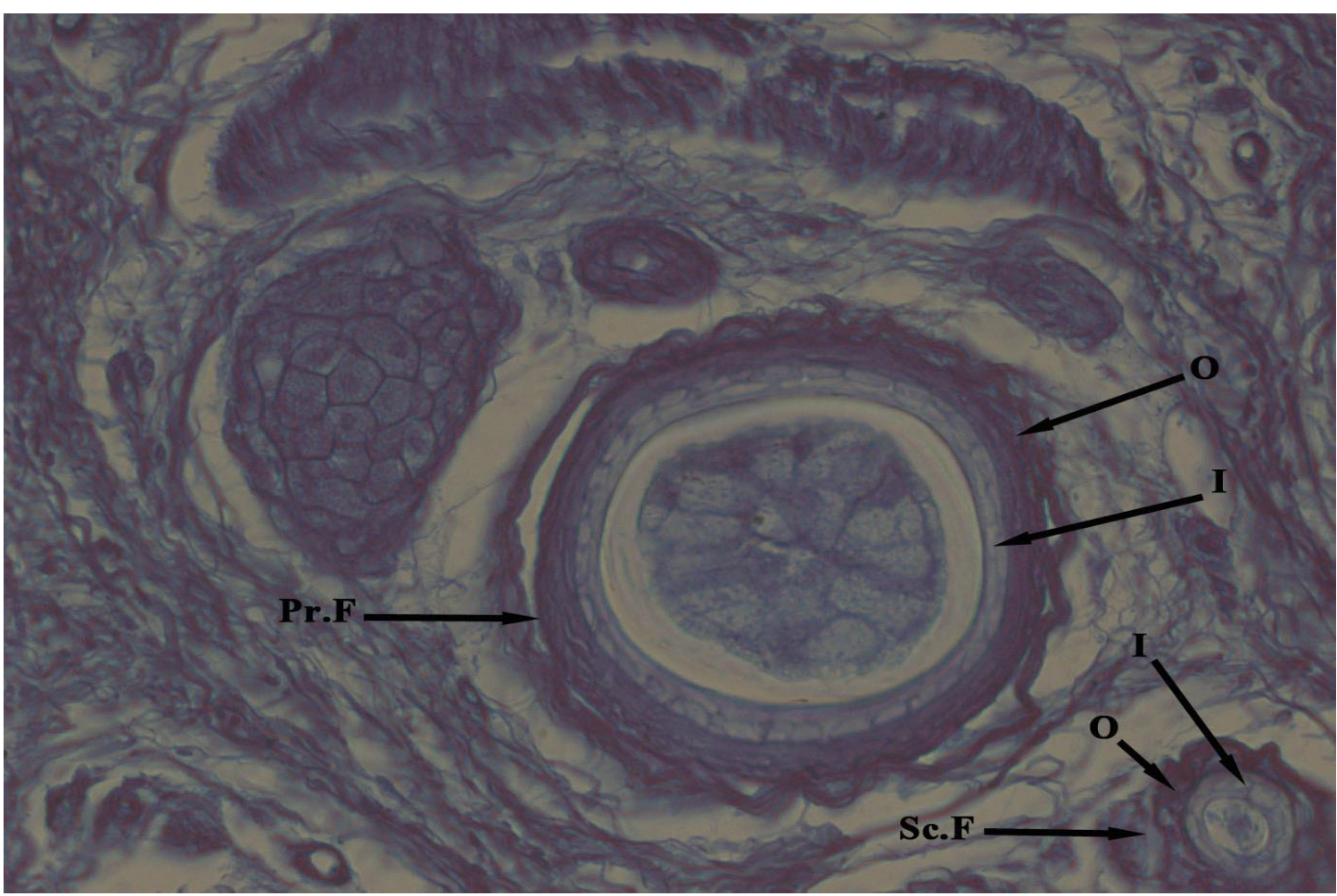

Figure (2): Transverse section in the wool follicle stained with bromophenol blue showing the distribution of general proteins in the different follicle sheaths. I, inner root sheath; O, outer root sheath; Pr. F., primary follicle; Sc. F., secondary follicle (X400). 


\section{Badawy}

Parmer et al. (1988) stated that the protein content was larger in the outer root sheath than that of the inner root sheath of the skin follicles and they ensured that the higher protein content in active wool follicle sheaths are associated with an increased protein synthesis in the cellular proliferation. The ultimate protein condition determining the rate of wool growth seems to be the condition of essential amino acids in the tissue fluids around the follicle, and whereas the supply of amino acids to the animal is determined by the amount and kind of protein. The synthetic potential of the proliferating cells of the follicles bulb is high relative to that of other tissues. In the present study, animals in group (3) possessed a significant increase in the general protein content of both outer $(0.77 \pm 0.02)$ and inner $(0.76 \pm 0.02)$ root sheaths of primary follicles than those in the other two groups. This indicate that follicle activity depends on materials used for production especially protein. In addition, energy intake can affect follicle activity and fibre production at high levels of protein intake Reis et al. (1988). El-Shaer and Kandil (1990) found that body weight changes of sheep and goats were significantly improved by adding source of energy to the basal diet, and this improvement was increased significantly with increasing the level of energy supplementation. They explained that the increase in body weight was due to the increase in dry matter intake from the saltbush because of energy supplementation.

In mohair production many authors illustrated that nutrition was a major determinant of follicle activity (Doyle et al., 1995 and Scobie et al., 1998). Liu et al. (2000) demonstrated that sulphur amino acids generally are most limiting for wool growth by mature sheep fed forage-based diets. Beside the effect of supplementations, grazing groups possessed an increase in the protein content of the primary follicle sheaths rather than the control group due to rising temperature; this was in agreement with the foundation of Abdou et al. (2007) who demonstrated more protein concentration in the two primary follicle sheaths in hot season than in cold season. On the other hand, grazing animals in group (2) recorded a non significant increase in the protein content of the outer and inner root sheaths $(0.73 \pm 0.02$, $0.69 \pm 0.02)$ versus $(0.72 \pm 0.02,0.68 \pm 0.02)$ for the control group respectively (Table 3$)$.

Table (3): The distribution of general proteins in the outer and inner root sheaths of primary and secondary wool follicles in the skin of sheep at different nutritional supplementations (expressed as means of optical density values).

\begin{tabular}{lcccc}
\hline \multirow{2}{*}{ Follicle type } & \multirow{2}{*}{ Sheaths } & \multicolumn{3}{c}{$*$ Nutritional treatments } \\
\cline { 3 - 5 } & & Group 1 & Group 2 & Group 3 \\
\hline \multirow{2}{*}{ Primary follicles } & Outer & $0.72 \pm 0.02^{\mathrm{b}}$ & $0.73 \pm 0.02^{\mathrm{b}}$ & $0.77 \pm 0.02^{\mathrm{a}}$ \\
& Inner & $0.68 \pm 0.02^{\mathrm{b}}$ & $0.69 \pm 0.02^{\mathrm{b}}$ & $0.76 \pm 0.02^{\mathrm{a}}$ \\
\multirow{2}{*}{ Secondary follicles } & Outer & $0.82 \pm 0.02^{\mathrm{a}}$ & $0.80 \pm 0.02^{\mathrm{a}}$ & $0.81 \pm 0.02^{\mathrm{a}}$ \\
& Inner & $0.81 \pm 0.02^{\mathrm{a}}$ & $0.79 \pm 0.02^{\mathrm{a}}$ & $0.80 \pm 0.02^{\mathrm{a}}$ \\
\hline
\end{tabular}

*Group 1 = In-door treatment feeding clover hay and supplemented with concentrate feed mixture (1\% of BW), group 2 and $3=$ grazing treatments supplemented with concentrate feed mixture ( 1 and $2 \%$ of $B W$, respectively). In each row, figures followed by different letters are significantly different $(P<0.05)$.

In contrast, the secondary follicles were slightly affected by both grazing and supplementary feeding (Table 3). Non significant increase of protein content in both outer and inner root sheaths of secondary follicles, $(0.82 \pm 0.02)$ and $(0.81 \pm 0.02)$ were found in animals of control group respectively. This result ensured the previous foundation that the secondary follicles were affected when exposed to high ambient temperature from free grazing in this arid region. Abdou et al. (2007) mentioned that, in both inner and outer root sheaths of secondary follicles the protein content was obviously lower in hot season.

The total output of the follicle is a direct function of the size of the germinative region of the bulb and the proliferative activity of the cell population of this region of the bulb. The rate of wool production by sheep is governed by the interaction between nutrition, genotype, and photoperiod, which alter both the rate of cell division in the germinative region of the follicle bulb and the protein synthesis in the keratogenous zone of the follicle (Black and Reis, 1979). Hynd and Masters (2002) reported that diets containing protein sources that are not only rich in S-containing and other essential amino acids, but also resistant to rumen degradation, would be affected positively on the wool growth.

The distribution of the general carbohydrates in the skin of the different supplemented groups is demonstrated in (Table, 4) and (Fig. 3). The highest carbohydrate content was localized in the outer root sheath of both primary and secondary follicles than that in the inner root sheath of all studied animals. This may be due to the assumption that the carbohydrates are considered as a sign of follicle activity as reported by Montagna (1956) who assumed that carbohydrates in the outer root sheath was the source of 
energy for protein synthesis during fibre growth. Also, it was the main source for glucose supply to the wool follicles which enhance energy requirements for active cellular proliferation. This confirms the results obtained by Abdou et al. (2002) in Baladi goats. Also, Helal and Hekal (2014) concluded that carbohydrate increased significantly in outer root sheath compared with inner root sheath. The strong activity for acid mucopolysaccharide was observed in the outer root sheath of goats (Parmar et al., 1988) and in sheep Taha et al. (2009) and Badawy (2006 and 2011).

Table (4). The distribution of general carbohydrates in the outer and inner root sheaths of primary and secondary wool follicles in the skin of sheep at different nutritional supplementations (expressed as means of optical density values).

\begin{tabular}{lcccc}
\hline \multirow{2}{*}{ Follicle type } & \multirow{2}{*}{ Sheaths } & \multicolumn{3}{c}{$*$ Nutritional treatments } \\
\cline { 2 - 4 } Primary follicles & Outer & $0.41 \pm 0.007^{\mathrm{a}}$ & Group 2 & Group 3 \\
& Inner & $0.38 \pm 0.006^{\mathrm{b}}$ & $0.40 \pm 0.007^{\mathrm{a}}$ & $0.39 \pm 0.007^{\mathrm{b}}$ \\
\multirow{2}{*}{ Secondary follicles } & Outer & $0.42 \pm 0.007^{\mathrm{b}}$ & $0.44 \pm 0.007^{\mathrm{b}}$ & $0.37 \pm 0.006^{\mathrm{b}}$ \\
& Inner & $0.40 \pm 0.007^{\mathrm{b}}$ & $0.43 \pm 0.007^{\mathrm{a}}$ & $0.44 \pm 0.007^{\mathrm{a}}$ \\
\hline
\end{tabular}

*Group 1 = In-door treatment feeding clover hay and supplemented with concentrate feed mixture (1\% of BW), group 2 and $3=$ grazing treatments supplemented with concentrate feed mixture (1 and $2 \%$ of BW, respectively). In each row, figures followed by different letters are significantly different $(P<0.05)$.

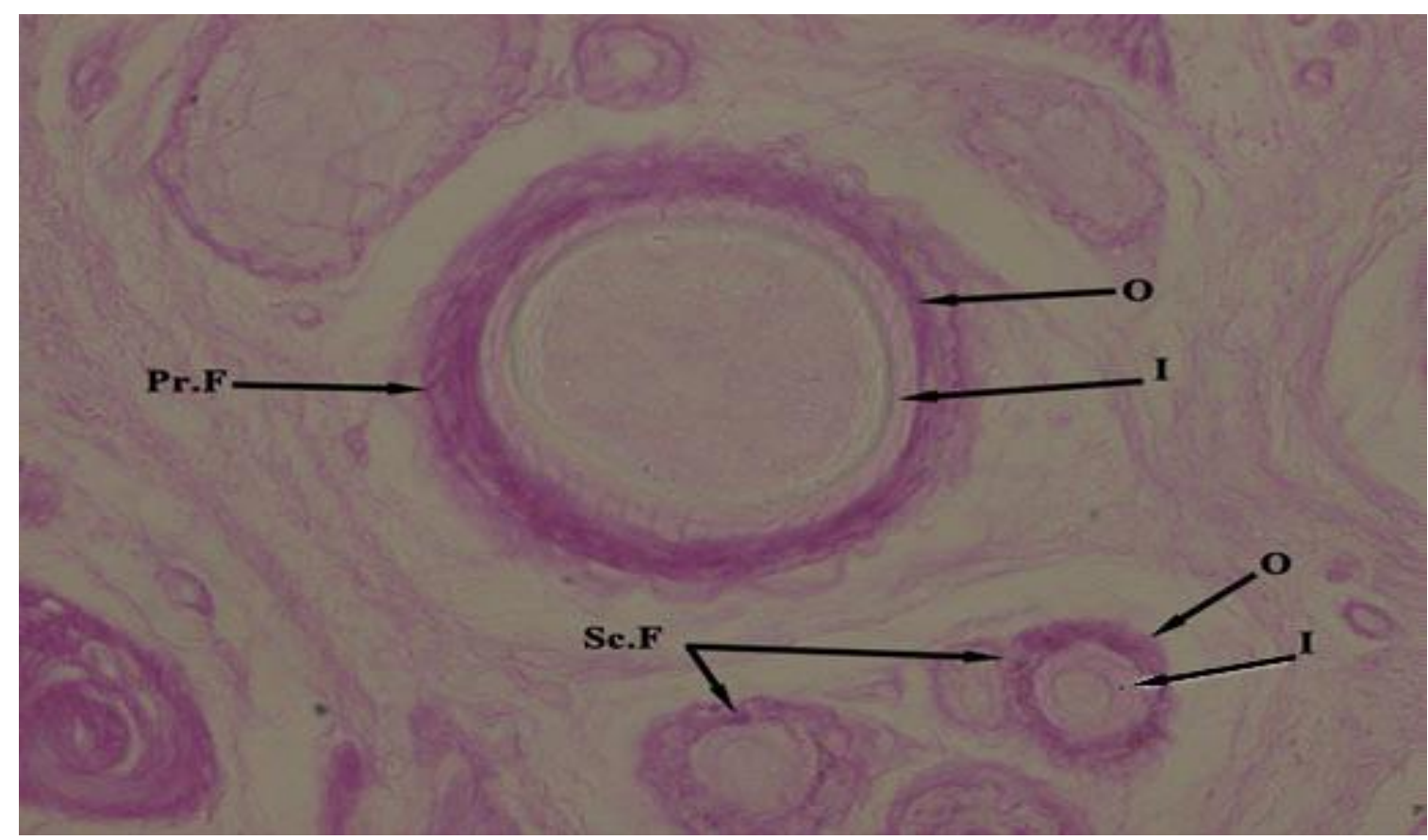

Figure (3): Transverse section in the wool follicle stained with Periodic acid Schiff showing the distribution of general carbohydrates in the different follicle sheaths. I, inner root sheath; $O$, outer root sheath; $P r . F$., primary follicle; Sc. F., secondary follicle (X400).

Carbohydrates are oxidized in the body to provide energy which is very important for wool growth. The explanation that carbohydrate frees protein for wool production which would otherwise have been used to provide energy is probably too simple. Carbohydrate is also needed in order that amino acids can be utilized and for mitosis to take place in the follicle bulb. Data in Table (4) demonstrated a significant decrease in the carbohydrate content of the outer root sheath of the primary follicles of animals in group (3) $(0.39 \pm 0.007)$ which was more supplemented than the other two groups. While in the inner root sheath of the same follicle a significant decrease was observed between group (2) and group (3) $(0.40 \pm$ $0.006,0.37 \pm 0.006$ ) was observed respectively. This could be attributed to the follicle activity which consumes more carbohydrates so stored carbohydrate content tended to decrease and vice versa as concluded by Helal and Hekal (2014). 


\section{Badawy}

In case of secondary follicles, and according to the previous results in Table (4), animals in control group demonstrated less carbohydrate content in the outer and inner root sheaths due to their activity $(0.42 \pm 0.007,0.40 \pm 0.007)$ rather than the other two groups which affected by grazing process $(0.44 \pm$ $0.007,0.43 \pm 0.007)$ for group (2) and $(0.46 \pm 0.007,0.44 \pm 0.007)$ for group (3). Generally, higher temperatures influence wool growth by causing dilation of the blood vessels of the skin, thus increasing the flow of nutrients to the follicles. Abdou et al. (2007) found more carbohydrate concentration in both secondary follicle sheaths in hot season. On the other hand, Kumar et al., (2000) reported that skin blood flow of male Murrah buffaloes increased after exercise and it could be due to increase in body temperature as a result of exercise resulted from metabolic heat production. Similar impacts of walking stress were reported on different kind of animals. In another point of view, Abdel-Fattah et al. (2008) concluded that providing probiotics in diets and exposed to walking stress would improve the hematological reactions in goats raised under the harsh conditions.

Supplementary feeding strategies provide the pastoralist with a management procedure which can stabilize nutrient intake at acceptable levels. In addition to the direct effects on sheep health and productivity, supplementation will reduce the effect of overgrazing as supplementary rations will substantially reduce forage intake, particularly when pasture is sparse. Generally, it could be concluded that the group of sheep which received supplementary feeding with double amount of concentrate showed more active follicles positively affecting their production and reduced the effect of grazing process on the animal performance.

The previous results indicated that energy represented the largest portion of the diet and is usually the most limiting nutrient in sheep diets. The presence of carbohydrates, fats and excess protein in the diet all contribute towards fulfilling the energy requirements of sheep. The major source of energy in sheep's diet are carbohydrates and concentrates which is a rich source of energy. While forages contain fibre or cellulose, which is not as rich in energy as concentrates. So, meeting energy requirements without over or underfeeding animals is one of the producer's biggest challenges. Energy deficiency is the most common nutritional deficiency in grazing sheep. With restricted energy consumption, wool growth slow, fibre diameter is reduced and weak spots develop in the wool fibre.

The present work illustrated that an increase in energy intake by feed supplementation usually has direct positive effect on wool growth in grazing sheep and this was confirmed by (Doney, 1983). Although the influence of feed intake on wool growth is well recognized, there is no disagreement on the roles of dietary energy and/or protein. Results from several experiments suggested that wool production is linearly related to intake, presumably digestive energy with protein intake having very little influence. So, more studies are needed to evaluate the effect of diets containing different levels of crud protein at different levels of intake as well as metabolizable energy and net energy values which are more accurate measures of energy in a sheep's diet on the growth and wool traits.

\section{REFERENCES}

Abdel-Fattah, M.S.; Y.M. Shaker; A.L.S. Hashem and A.A. Azamel (2008). Effect of probiotics and walking stress on some physiological and heamatological parameters of Hassani goats. J. Agric. Sci. Mansoura Univ., 33(8): 5581-5593.

Abdou, A.S.; M.M. El-Ganaieny; F.I. Khattab and S.A. Hekal (2002). Seasonal changes of the histology and histochemistry of the hair follicles of Baladi goats in Egyptian desert areas. J. Agric. Sci. Mansoura Univ., 27 (6): 3721-3736.

Abdou, A.S.; S.A.A. Hekal and H.S. Khamis (2006). Effect of supplementary feeding under different grazing conditions on the skin follicles and hair coat in camels raised at Halayeb, Shalateen and Abou Ramad triangle, Egypt. Egyptian J. Anim. Prod., 43(2): 139-151.

Abdou, A.S.; H.H. Swelim; N.A. El-Sayed and N.S. Badawy (2007). Histochemical changes of wool follicles and skin glands of some local sheep breed in Hederbah vally during different seasons. Egyptian. J. Basic Appl. Physiology. 6 (2): 341-360.

Askar, A.R.; R. Salama; H.M. El-Shaer; M.A. Safwat; M. Boraei; M.S. Nassar and O. Raef (2012). Feasibility of AIA and ADL to estimate daily feed intake and digestibility in sheep fed natural rangelands under arid condition. Egyptian J. Nutr. Feeds 15, 160. 
Askar, A.R.; R. Salama; H.M. El-Shaer; M.A. Safwat; M. Poraeib; M.S. Nassar; H.S. Badawy, and O. Raef (2014). Evaluation of the use of arid-area rangelands by grazing sheep: Effect of season and supplementary feeding. Small Ruminant Research 121: 262-270.

Badawy, N.S. (20011). impact of some pollutants on the skin and coat characteristics of sheep raised in some locations at El-Salam Canal Ph. D. Thesis, Fac. Sci. Univ., Ain Shams, Cairo, Egypt.

Badawy, N.S. (2006). Histological and histochemical studies on the skin of local sheep breeds in Halaieb, Shalateen and Abou Ranad triangle. M. Sc. Thesis, Fac. Sci. Univ., Ain Shams, Cairo, Egypt.

Barker, J.R. (1958). Principles of Biological Technique. London, Methuen, New York, John Wiley, Bancroft. J. D.

Black, J.L. and P.J. Reis (1979). Speculation on the control of nutrient partition between wool growth and other body functions. In Physiological and Environmental Limitations to Wool Growth. (Eds. J.L. Black and P.J. Reis) pp 29-294. (University of New England Publishing Unit: Armidal).

Cartwright, G.A. and C.J. Thwaites (2000). The effects of high ambient temperature during gestation on wool follicle development in the fetal lamb. J. Agric. Sci. 86: 581-585.

Chapman, D.M. (1975). Dichromation of bromophenol blue with an improvement in the mercuric bromophenol blue technique for protein. Stain Technology., 50: 25-30.

Doney, J.M. (1983). Factors affecting the production and quality of wool. In Sheep Production. Edited by P.W. Haresing. London. Butterworths.

Doyl, P.T.; T.W. Plaisted and R.A. Love (1995). Supplementary feeding pattern and rate of live weight gain in winter-spring affect wool production of young Merino sheep on south coast of Western Australia. Australian Journal of Experimental Agriculture, 35(8): 1093-1100. (Nutritional Abst. And Reviews, 66 (6): 2743).

Drury, R.A.B. and E.A. Wallington (1980). Carleton's Histological Technique. $5^{\text {th }}$ Ed. Oxford University Press. Oxford, UK., 520.

El-Ganaieny, M.M. and A.S. Abdou (1999). A histological study on skin hair follicles of Baladi goats. Minufiya J. of Agric. Res. Vol. 24, No. 20 (1) 469-480.

El-Shaer, H.M.; H.M. Kandil; H.M. Abou El-Naser and H.S. Khamis (1997). Features and constraints of animal resources development in Shalateen-Halaib region. Egyptian Journal of Nutrition and Feeds, 1: $121-128$.

El-Shaer, H.M. and H.M. Kandil (1990). Comparative study on the nutritional value of wild and cultivated Atriplex halimus by sheep and goat in Sinai. Comput. Sci. Dev. Res. 29, 81-90.

Ferrell, C.L.; K.K. Kreikemeier and H.C. Freetly (1999). The effect of supplemental energy, nitrogen, and protein on feed intake, digestibility, and nitrogen flux across the gut and liver in sheep fed lowquality forage. J. Anim. Sci. 77, 3353-3364.

Helal, A. and S.A. Hekal (2014). Hair and follicles characteristics during summer and autumn seasons of Shami goat raised in North Sinai. Journal of American Science 10(8): pp 191-198.

Hynd, P.I. and D.G. Masters (2002). Nutrition and wool growth. In: Sheep nutrition. CAB. Int., pp: 400.

Kabir, F.; M.S. Sultana; M. Shahjalal; M.J. Khan and M.Z. Alam (2004). Effect of protein supplementation on growth performance in female goats and sheep under grazing condition. Pakistan J. of nutrition 3(4): 237-239.

Khan, M.J.; A. Abbas; M. Ayaz; M. Naeem; M.S. Akhter and M.H. Soomro (2012). Factors affecting wool quality and quantity in sheep. African Journal of Biotechnology Vol. 11(73), pp. 13761-13766.

Kochapakdee, S.W.; S. Pralokarn; A.S. Laapetchara and B.W. Norton (1994). Grazing management studies with Thai goats. Productivity of female goats grazing newly established pastures with varying levels of supplementary feeding. Asian Aust. J. Anim. Sci., 7: 289-293.0

Kumar, P.; S.V. Singh; R.C. Upadhyay and A.A. Aggarwal (2000). Skin blood flow during pre and post treadmill exercise in buffaloes. Indian J. of Anim. Sci., 70(2): 178-179.

Liu, D.; D.J. Schingoethe and G.A. Stegeman (2000). Corn distillers grains versus a blend of protein supplement with or without ruminally protected amino acids for lactating cows. J. Dairy Sci., 83: 2075- 2084. 


\section{Badawy}

Mc-Gregor, B.A. (1990). Nutritional, seasonal, management and processing factors affecting mohair quality and quantity. In: K. Thompson (Co-ordinator) Goat Health and Production, Refresher Course for Veterinarians, Proc. 134. P 347. Univ. of Sydney, Sydney, Australia.

Mc-Manus, J.P.A. and J.E. Cason (1950). Carbohydrate histochemistry studied by acetylation techniques periodic acid method. J. Exp. Med., 91: 651.

Montagna, W. (1956). The structure and function of skin. New York; Academic Press.

Parmar, M.L.; R.D. Sinha; G. Parasad and J. Prasad (1988). Histochemical studies on hair follicles and sebaceous and sweat glands in goat. Ind. J. Anim Sci., 58 (7): 789-791.

Reis, P.T.; D.A. Tunks and S.G. Munes (1988). Relative importance of amino acids and energy for wool growth. Proceeding of the nutrition society of Australia. 13: 122.

Rowe, J.B.; G. Brown; I.G. Ralph; J. Ferguson and J.F. Wallace (1989). Supplementary feeding of young Merino sheep, grazing wheat stubble, with different amounts of lupin, oat or barley grain. Australian Journal of Experimental Agriculture 29(1) 29-35.

SAS, (2004). Statistical Analysis System Institute, SAS User's Guide Statistics, SAS Institute Inc., Cary, NC.

Schleger, A.V. and H.G. Turner (1960). Analysis of coat characteristics of Cattle. Aust. J. Agric. Res., 12: 176-202.

Scobie, D.R.; A.R. Bray and N.C. Merrich (1998). Medullation and average fibre diameter vary independently in the wool of Romney sheep. N. Z. J. of Agric. Res., 41 (1): 101-110. (Anim. Breed. Abst., 66 (9): 6185.

Taha, E.A.T.; A. H. Samia and A.H. Mahmud (2009). Some wool characteristics of Barki sheep fed on some halophytes under desert conditions. J. Agric. Sci. Mansoura Univ., 34(1): 151-166.

Whiteley, K.J. (1984). Quantitative importance of wool characteristics in processing. In Proceedings of Seminar on Wool Production in Western Australia. (Eds. S.K. Baker, D.G. Masters and I.H. Williams) pp 1-15. (Australian Society of Animal Production). W.A. Branch: Perth.

Zen (2012). Carl Zeiss Microscopy GmbH, www.zeiss.com/microscopy. 
تأثير التغذية التكميلية على خصائص الجلد والغطاء الخارجى للأغنام فى مثلث حلايب وشلاتين وأبو رماد

نجلاء سالم بلدوى

قسم إنتاج وتكنولوجيا الصوف، مركز بحوث الصحراء، المطرية، القاهرة.

ـ أجريت هذه الدراسة علي عدد 15 من النعاج البالغة تتراوح أعمار ها مابين 2-4 سنوات بمتوسط وزن الجسم 30 كجم وذلك لدراسة

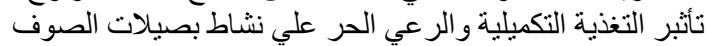

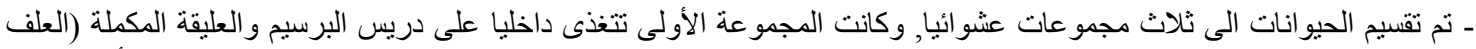

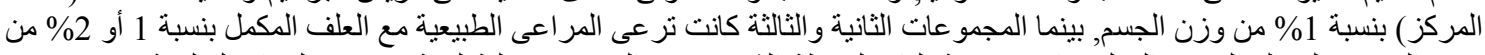

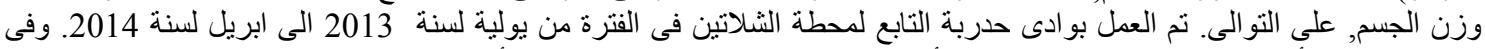

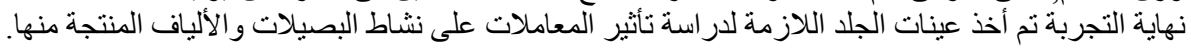

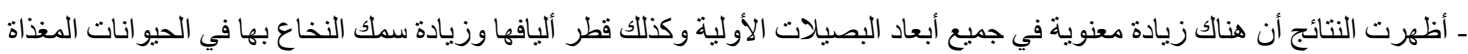

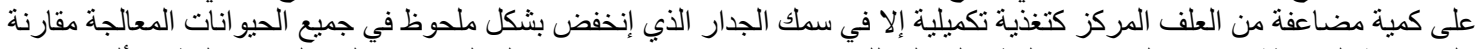

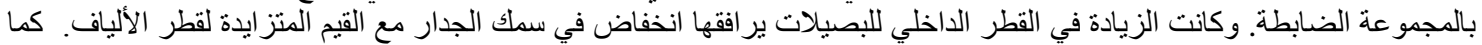

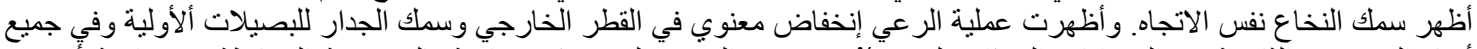

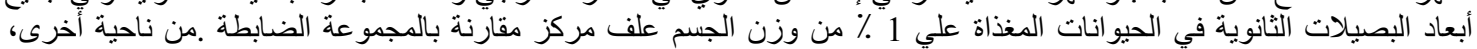

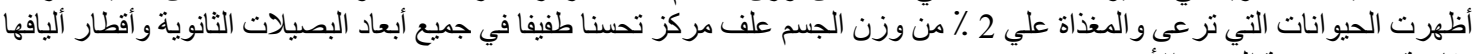

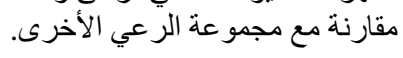

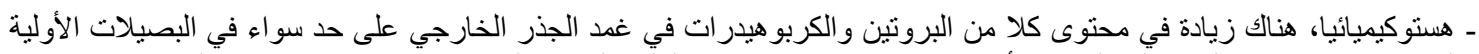

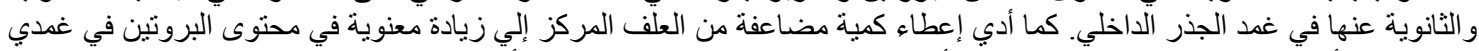

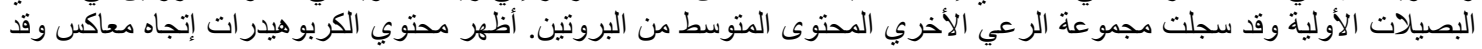

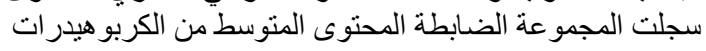

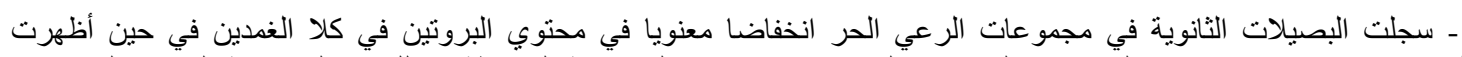

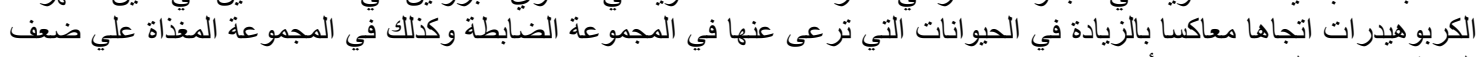
الكمبية عنها في المجمو عات الأخري.

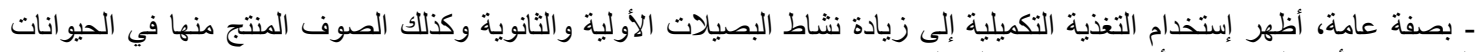
الر اعية مما أدى إلى خفض تأثير إجهادات عملية الرعي. 